\title{
Introduction: Gender Issues in Contemporary Irish Literature
}

\author{
Melania Terrazas \\ University of La Rioja, Spain
}

Copyright (c) 2018 by Melania Terrazas. This text may be archived and redistributed both in electronic form and in hard copy, provided that the author and journal are properly cited and no fee is charged for access.

To mark International Women's Day on 8 March 2016, the Irish Times invited more than 40 Irish writers, critics, and academics to nominate their favourite Irish woman writer. The result was a poster featuring 12 widely acclaimed authors described by Martin Doyle, editor of the Irish Times, as "a deliberate pastiche of the various familiar Irish Writers posters, which do not have even a token woman among their 12 featured writers (echoing the famous Field Day Anthology of Irish Writing affair in 1990, which was so bereft of female writers that an extra volume had to be commissioned to atone)" (Doyle).

This was the intention behind the XVI International AEDEI Conference held at the University of La Rioja in May 2017. This meeting aimed at both the reassessment of former ideological dogmas concerning gender issues and the exploration of new trends in gender in Irish studies because, as Anne Enright points out, there is "a confidence in female voices that" she had not "seen ever before - a hugely important thing". As organizer of the conference, I wanted to interrogate that aspect of Irish writing, since, as Enright continues: "Traditionally, Irish writing has been about breaking silences. The biggest silence has continued to be about the real lives of women" (qtd. in Lavan). My interest in this examination of "the real lives of women" was reinforced by a reading of Sinéad Gleeson's recent anthologies of short stories by Irish women, The Long Gaze Back (2015) and The Glass Shore (2016), which showcase 56 stories revealing that, as Gleeson notes, "The old patterns of male-dominated anthologies, men-only book panels and reverence around men's writing are finally changing" (qtd. in Jordan).

Having said this, the decision to edit this issue was prompted by one question: Why have women and gender in Irish studies achieved such relevance recently? My interest to work on this area coincides with a time in which Ireland is becoming more culturally liberal in many respects. We have witnessed Irish citizens voting in a referendum to legalize divorce, contraception, and in 2015, supporting same-sex marriage. On 25 May 2018, the referendum to repeal the Eighth Amendment of the Constitution was joyfully celebrated around Ireland and the world, placing the country, which elected a gay, mixed-race prime minister in 2017, at the leading edge of a social revolution, beyond being a historic day for Ireland. The present special issue aims to contribute to the critical debate on women's lives and gender in Irish studies. 
Since the late 1990s, we have seen the publication of rigorously multidisciplinary investigations of Irish studies from gender and other theoretical perspectives. James M. Cahalan's Double Visions: Women and Men in Modern and Contemporary Irish Fiction (1999) is just one example. Cahalan examines gender issues by comparing men's representations of women with women writers' characterization of men. He also dwells on other distinctions, such as class and region, revealing differences in perceptions of subjects such as politics and autobiography to clarify a number of double visions.

Other productive integrations of feminist theory and the postcolonial approach in Ireland include Elizabeth Butler-Cullinford's Ireland's Others: Gender and Ethnicity in Irish and Popular Culture (2001), Claire Connolly's Theorizing Ireland (2002), and Claire Carroll and Patricia King's Ireland and Postcolonial Theory (2003). Marisol Morales focuses on gender from the same approaches in Postcolonial and Gender Perspectives in Irish Studies (2007) with a similar level of rigour. These four books bear witness to the thriving state of postcolonial and gender studies in Ireland, North America, and Spain, illuminating the connections between national identity, gender, and sexuality.

More recently, Patricia Coughlan and Tina O'Toole's collection Irish Literature: Feminist Perspectives (2008) has discussed texts from the early eighteenth century to the present day, renegotiating the relationship between nationalism and feminism, making an important contribution to contemporary debates about ideology, gender, and Irish culture. Ellen McWilliams's Women and Exile in Contemporary Irish Fiction (2013) examines how contemporary Irish authors have taken up the history of the Irish woman migrant. Finally, Elke D'hoker's Irish Women Writers and the Modern Short Story (2016) traces the types of influence that link 15 well-known writers, the specific use each makes of the short story form, and the thematic concerns they bring to the genre. In doing so, these works that draw on the intersection between various theoretical schools of criticism and gender studies, and include the two political and geographic spaces that constitute the island of Ireland, provide well-argued insights and show that gender studies is flourishing in Ireland.

Gender Issues in Contemporary Irish Literature aims to complement all these studies. The articles which follow approach the representation of gender issues by various fe/male authors from the Republic of Ireland from a wide variety of perspectives, namely, ecofeminism, new materialism, translation, gay studies, feminism, aesthetic ideology, masculinity studies, formalism, narratology, discourse analysis, and satire theory. They seek to address a wide range of gender issues in both literature and film in a multifaceted manner.

The issue is divided into three sections. The works under examination in the first two parts are organized in chronological order. In the near future, it would be very interesting to pursue further projects on gender issues in contemporary literature from Northern Ireland as a part of the United Kingdom or to compare gender issues in contemporary Irish literature from north and south, since that position would provide a clarifying frame for the issue. The third section closes the issue with two reflective pieces by the talented young writer Rob Doyle and the renowned short-story writer and novelist Evelyn Conlon.

The issue assembles a varied group of scholars whose essays ensure deep and wide coverage and highlight significant thought and areas of debate. More concretely, it seeks to highlight the particular contribution that the study of contemporary Irish literature and film has made, and continues to make, to gender issues. By attending to the relationships between material and filmic texts of different genres, such as prose writing, theatre, the epistemological novel, the Bildungsroman, and dystopian fiction by a large number of contemporary Irish writers both male and female, and film directors, the collection sheds light on questions related to working-class issues, environmental ethics, human epistemology, identity, migration, feminism, political correctness, the body, the value of attending closely to aesthetic forms, and the ethical implications concerning gender issues. Gender Issues in 
Contemporary Irish Literature seeks to assist both established and new scholars of gender to come to terms with the full extent of Irish studies advances.

Opening the collection, José Lanters's "Groping towards Morality: Feminism, AIDS, and the Spectre of Article 41 in Thomas Kilroy's Ghosts" focuses on the origins of Kilroy's adaptation of Ibsen's Ghosts, which he transposes to contemporary Ireland, and whose focus is on marriage, the AIDS crisis, and the position of the Catholic Church regarding women and homosexuality. Lanters traces the intertextual process which makes Ibsen's play relevant to an Irish setting in 1989.

Maureen O'Connor offers the first scholarly examination of Tim Robinson's prose writing in "'Informed Love': Human and Non-Human Bodies in Tim Robinson's Ethical Aesthetic". O'Connor establishes a rich theoretical framework grounded in feminist materialism resulting in a subtle analysis of Robinson's environmental ethic. Her reading of Robinson's work opens up important critical debates on his legacy and the relevance of establishing a viable environmental consciousness today.

Two essays on John Banville's fiction - "The 'Woman' as a Frame for the Self: Femininity, Ekphrasis, and Aesthetic Selfhood in John Banville's Eclipse, Shroud, and Ancient Light" by Mehdi Ghassemi and "The Role of Female Characters in the Narrator's Quest for Identity in John Banville's Eclipse" by Mar Asensio - provide highly nuanced interpretations of the multiple prize-winning author. The first piece is an approach to Banville's Cass Cleave trilogy and, more particularly, to its main protagonist's concept of the self as unfinished. Ghassemi focuses on Banville's depiction of women in the trilogy following theoretical and aesthetic assumptions proposed by Nietzsche and Paul de Man and as part of Banville's exploration of alterity. Asensio's essay examines the representation of women in Banville's Eclipse and dwells upon the shift that occurs in his œuvre with regard to women's "role" in the narrator's quest for authentic subjectivity. Asensio also explores the spectral quality of many of the characters in Eclipse.

The last essay in the male fiction section, José Díaz Cuesta's "Representations of Masculinities in John Michael McDonagh's Satirical Film Text The Guard", discusses the film from a gender perspective, illuminating two key concepts: satire and political correctness. The essay also provides numerous insights into McDonagh's translation of the buddy film from an American to an Irish context.

Part two opens with Alicia Muro's essay "The Modernization of William Shakespeare's Hamlet: Identity and Gender in Irish Murdoch's The Black Prince", which discusses the latter's sense of Irishness. Muro draws a connection between Julian in The Black Prince and Ophelia in Hamlet and asserts the importance of the unreliability of the narrator in Murdoch's novel and its metafictional aspect. Finally, Muro discusses how Shakespeare's Hamlet is reimagined in Murdoch's novel, and why the latter is worth including in a special issue on contemporary Irish fiction.

Edurne Goñi looks at Bernard Shaw's play Pygmalion, which was translated and performed in Spain in 1919. In "Translating Characters: Eliza Doolittle 'Rendered' into Spanish", Goñi notes that the play was translated into Spanish four more times between 1919 and 2016, and argues that these translations fail to convey its "real meaning". To prove this, she focuses on examples of Eliza's speech. Her analysis of the changes introduced by the various translators shows that the character is presented differently, which affects the meaning/s of the play.

In "Thematic Transgressions and Formal Innovations in Edna O'Brien's The Country Girls Trilogy and Epilogue", María Amor Barros del Río asserts that the trilogy is now acknowledged as a female Bildungsroman. However, by looking into the political implications of its central theme, as well as the structural and formal innovations employed by 
O'Brien to represent the impossibility of a female Bildung in the traditional form, she shows the need to reconsider the place of the trilogy within the panorama of Irish literature.

Ekaterina Muraveva's "Exploring Advertising Discourse Critique and Female Identity Problem in The Dystopian World of Louis O'Neill's Only Ever Yours" focuses on gender issues in this thought-provoking novel from a multidisciplinary perspective based on critical discourse analysis and satire theory. Muraveva interrogates media through the novelist's use of advertising discourses, providing a poignant critique of familiar schemes and patterns through the dystopian setting of O'Neill's novel. In this way, Muraveva shows how O'Neill unearths problematic issues of female identity and various stereotypes related to beauty myths, objectification, the female body, commodification, ageism, and subversive public practices.

The powerful fiction of Rob Doyle often presents Irish traditional forms and themes in unflinching and provocative ways, revealing a young Irish generation who do not care for feelings. Doyle's reflection piece on gender maintains some of these traits, yet his text is also honest and delicately ponders issues that often provoke anger. Doyle adroitly offers his perspective on the controversial issue of modern masculinity.

Evelyn Conlon needs no introduction. She has long expressed concern for gender issues in Ireland and supported the Women's Liberation Movement in Ireland since the early 1990s. In the piece which closes this special issue, Conlon reflects upon what literature is, how it influences one's personality and way of thinking, how it helps to shape one's mind, and how it facilitates the expression of new truths. Conlon reflects on how male literature has mediated the representation of women and humanity in general in the past, how it continues to do so, and how women have been and continue to be misrepresented in Irish and other world literatures. Following Conlon's example, my intention is for this issue to question why being a woman - whether she is single, divorced, or married, whether her partner is male or female, whether she decides to become a mother or have an abortion - is an issue at all.

Undertaking this special volume on Gender Issues in Contemporary Irish Literature has been a truly life-changing experience for me and it would not have been possible without the support and guidance that I received from many people. I want to thank the Spanish government, who provided a Salvador de Madariaga Visiting Scholarship, which granted funding for my research at NUI Galway last winter. The research on which this special issue is based was also funded by research project reference number APPI17/06 (Vicerrectorado de Investigación - University of La Rioja). I am grateful to EMYDUR (Escuela de Máster y Doctorado de la Universidad de La Rioja) for their support. This line of research is also in tune with the objectives of the Centre of Irish Studies BANNA/BOND (EFACIS) and Research Group GRID (University of La Rioja). I would like to first say a very big thank you to the General Editor of Estudios Irlandeses José Francisco Fernández, for trusting me to carry out this project and for all the support and encouragement he gave me during the months I spent at Huston School of Film Studies and Digital Media and The Moore Institute for Research in the Humanities and Social Studies at NUI Galway, Ireland, designing the project, and also throughout the whole process at the University of La Rioja, Spain. Without his guidance and constant feedback this special volume would not exist. My deep appreciation also goes out to Seán Crosson, Daniel Carey, Tina-Karen Pusse, Muireann O'Cinneide and Chloe Graham for their support and help at NUI Galway.

This volume would not have been possible without the assistance of many people. First and foremost, I would like to thank all the contributors with whom I have had the pleasure to work during this project. Each of them has taught me a great deal about their subject. I gratefully acknowledge the help offered by all the members of the magnificent editorial committee of Estudios Irlandeses who read and refereed all the contributions to this volume. Many thanks for your time, unstinting commitment, and invaluable comments and 
suggestions on the essays submitted. My thanks also for the support I received from other academics who are not on the editorial team of the journal, but were more than willing to read the papers and offer their most valuable and generous feedback for the authors. My most sincere gratitude to María Losada, Aida Rosende, Cahal McLaughlin, Anna Bugajska, Mária Kurdi, Mehdi Ghassemi, Joseph McMinn, Riana O'Dwyer, Rebecca Graham, Christine Cusick, Joakim Wrethed and last, but not least, Alwyn Harrison. Thank you very much all of you for your help.

Finally, I would also like to say a heartfelt thank you to my two children, Sonia and Manuel, for always believing in me and encouraging me to follow my dreams.

\section{Works cited}

Doyle, Martin. "Putting Irish Women Writers Back in the Picture". Irish Times. 23 February 2015. 18 June 2018. https://www.irishtimes.com/culture/books/putting-irish-womenwriters-back-in-the-picture-1.2113897

Jordan, Justine. “A New Irish Literary Boom: The Post-crash Stars of Fiction”. Guardian. 17 October 2015. 18 June 2018. https://www.theguardian.com/books/2015/oct/17/newirish-literary-boom-post-crash-stars-fiction

Lavan, Rosie. "Enduring Fictions: Celebrating The Long Gaze Back". Irish Times. 4 April 2018. 18 June 2018. https://www.irishtimes.com/culture/books/enduring-fictionscelebrating-the-long-gaze-back-1.3450501

Melania Terrazas is Senior Lecturer in English Studies at the University of La Rioja (Spain). She is the author of Relational Structures in Wyndham Lewis's Fiction: Complexity and Value (Lincom Europa, 2005) and helped set up the Wyndham Lewis Project website. She has published essays on Applied Linguistics (vocabulary knowledge and motivation) and extensively on British Modernism and a number of Irish authors and film directors (gender, satire theory, migration and trauma). She is on the Executive Board of AEDEI (The Spanish Association for Irish Studies) and is Head of the Centre of Irish Studies BANNA/BOND (EFACIS) at the University of La Rioja. She was the editor of Journal of English Studies and, at present, she is editing a volume on trauma and identity issues in contemporary Irish culture.

melania.terrazas@unirioja.es 